\title{
DESAFÍOS DE LA RESPONSABILIDAD CIVIL EN INTERNET. UNA REALIDAD COMPLEJA EN BRASIL
}

\author{
CHALLENGES OF CIVIL RESPONSIBILITY ON THE INTERNET. \\ A COMPLEX REALITY IN BRAZIL
}

\author{
JANNY CARRASCO MEDINA* \\ INEZ LOPES MATOS**
}

\section{RESUMEN}

El establecimiento y la dominación de ciertas empresas transnacionales en el mundo virtual, los gigantes de internet, ha provocado una complejidad sin precedentes en el campo de la responsabilidad civil. La búsqueda de elementos de conexión existentes en los conflictos generados en la web, ha permitido identificar varios caminos para la determinación de la jurisdicción aplicable, con el fin de dar solución a los daños provocados en internet y que terminan teniendo impacto en la vida off-line. El presente artículo tiene como objetivo general determinar los principales desafíos que enfrenta la responsabilidad civil individual en internet, desde la perspectiva del derecho brasileño, a fin de solucionar los litigios transnacionales generados en este espacio, tanto por violaciones provenientes de terceros como de parte de los gigantes de internet.

Palabras Claves: derecho internacional privado, internet, responsabilidad civil.

\footnotetext{
* Profesora de Derecho Internacional, Universidad de Brasilia. Dra. en Derecho Internacional por la Universidad de Brasilia. Master en Educación Superior por la Universidad Marta Abreu Las Villas, Cuba. Licenciada en Derecho por la Universidad Marta Abreu Las Villas, Cuba. Correo electrónico: jannycarrasco83@gmail.com

** Profesora de Derecho Internacional, Universidad de Brasilia. Coordinadora del Grupo de Investigación de Estudios de Derecho Internacional Privado, Comercio y Derechos Humanos. Master en derecho del trabajo y globalización por la Universidad de Kassel en Alemania. Bachiller en Derecho por la Universidad Católica de Santos, Sao Paulo. Correo electrónico: inezlopes@gmail.com Artículo recibido el 21 de febrero de 2019 , y aceptado para su publicación el 3 de junio de 2019.
} 


\section{ABSTRACT}

The establishment and domination of certain transnational corporations in the virtual world, the giants of the Internet, has led to unprecedented complexity in the field of civil responsibility. The search for connection elements existing in the conflicts generated on the web, has made it possible to identify several paths for the determination of the applicable jurisdiction, in order to solve the damages caused on the internet and that end up having an impact on the off-line world. The objective of this article is to determine the main challenges faced by individual civil responsibility on the Internet, from the perspective of Brazilian law, in order to solve the transnational legal issues generated in this space, both for violations by third parties and from the internet giants.

Keywords: Private International law, Internet, Civil responsibility.

\section{INTRODUCCIÓN}

Si el conocimiento es poder en palabras de Francis BACON, el intercambio de conocimiento es poder multiplicado, según Robert NoYCE. Las innovaciones tecnológicas en el área de las telecomunicaciones y la informática, principalmente con la invención del internet y de la red mundial de computadores (world wide web), dieron origen a la sociedad de la información, facilitando la creación de una base de datos jamás vista anteriormente, la Big Data. La economía digital o del conocimiento, se basa en la explotación del uso, almacenamiento, producción y/o transformación de la información guardada en bases de datos que se han expandido velozmente, generando muchas veces una riqueza superior a la de la economía industrial.

La expansión de los servicios de comunicación e informática posibilitó un crecimiento astronómico en las cifras de personas conectadas a internet. Según la Unión Internacional de Telecomunicaciones (UIT), internet posee casi cuatro mil millones de usuarios, lo que representa cerca del $53 \%$ de la población mundial. La mayor concentración se encuentra en los países desarrollados con una tasa del $81 \%$ de penetración, seguido por los Estados en vías de desarrollo con el $40 \%$ y los menos desarrollados, con el 15\%. Brasil posee altos niveles de conexión con 98 millones de usuarios, lo que 
representa casi la mitad de su población. ${ }^{1}$

Internet constituye una obra de la ingeniería computacional, que facilitó la comunicación global a través de una red de computadores interconectados mediante un conjunto de protocolos, como el protocolo de control de transmisión (TCP); el protocolo de internet (IP), el protocolo de transferencia de archivos (FTP) y el protocolo de transferencia de hipertextos (HTTP), entre otros. Por su parte, la web es la arquitectura del ciberespacio, que ofrece al usuario de la red servicios de comunicación de datos (textos y/o multimedia), sea como productor o consumidor de informaciones. Tim Berners-LeE, padre de la web, garantizó el acceso libre a escala mundial, facilitando con ello la democratización de las informaciones.

Con la popularización del uso de internet, las informaciones que circulan, así como los datos personales, pasan a tener un alto valor económico, propiciando que los gigantes de internet desarrollen programas con capacidad de almacenar y utilizar económicamente las informaciones de los usuarios a partir de enormes bases de datos, sistema denominado como Big Data o gran masa de datos.

La era digital transformó la manera de propagación y relación de las personas con el conocimiento, delimitadas anteriormente por los espacios físicos. Esto hizo que el ser humano se convirtiera en un producto en sí mismo y por ello, las redes sociales poseen un valor asociado al número de usuarios participantes: cuanto mayor es el número de clicks, mayor es el valor de la empresa en el mercado. El intercambio inocente de usuarios en la red alimenta las bases de datos, transformándose en un commodity ${ }^{2}$ tan importante como pueden serlo productos tradicionales del mercado global.

La ubicuidad y desterritorialización que marcan el ambiente virtual estrecha las distancias entre regiones y países, y existe cada vez más una proliferación de actos jurídicos celebrados en estos espacios abarcando las más diversas áreas del conocimiento. La responsabilidad civil en el derecho, objeto central de este trabajo, está definida básicamente por aquella acción u omisión que causa daño a otro y que tiene el deber de reparar el perjuicio causado. En las relaciones jurídicas en la red ¿Pueden ser responsabilizados los proveedores de servicios por actos practicados por sus usuarios? ¿Cuáles son los límites de su responsabilidad? El presente artículo tiene como objetivo general determinar los principales desafíos que enfrenta la responsabilidad

\footnotetext{
' SANou, Brahima, ICT facts and figures 2018, International Telecommunication Union, Ginebra, 2018.

2 Mazumder, Anirban, Database Law: Perspectives from India, Springer, Singapore, 2016, p.2.
} 
civil individual en internet, desde la perspectiva del derecho brasileño, a fin de solucionar los litigios transnacionales generados en este espacio.

\section{RELACIONES JURÍDICAS COMPLEJAS EN LA WEB}

\section{Generalidades y conceptos.}

En términos de Fabio UlLOA la relación jurídica es el vínculo entre dos sujetos, entre los cuales se entrecruzan derechos y obligaciones. ${ }^{3}$ Pues bien, en el espacio virtual, estas relaciones jurídicas se tornan más complejas.

El negocio jurídico virtual propicia la transnacionalización de las actividades civiles y comerciales. Esa característica dificulta un control exacto de los flujos transfronterizos, lo que hace necesaria la existencia de una regulación al respecto. Por regla general, los proveedores de internet son clasificados en: (i) proveedores de conexión, aquellos que propician el acceso de servicios de internet (en el caso de Brasil, Net Virtual, Brasil Telecom, Gvt y Tim, Oi, Claro, Vivo en la banda 3G-4G); (ii) el proveedor de correo electrónico, aquel que facilita intercambio de comunicación entre destinatarios (Gmail, Yahoo!, Hotmail); y (iii) el proveedor de información y contenidos, que prestan servicios como redes sociales o canales de música como Google+, Facebook, WhatsApp, Twiter, Youtube, Spotify. ${ }^{4}$ La Ley Marco Civil de Internet (Ley No 12.265, del 23 de abril de 2014, Brasil), en cambio, los clasifica en dos tipos de proveedores: (1) los de conexión (servicios de acceso a internet por los usuarios) y (2) los de aplicaciones (servicios de contenidos). ${ }^{5}$

En ese sentido, LOPES afirma que el consumidor ya no está vinculado solo a su mercado interno, pues el fenómeno de la globalización alcanza hasta el último eslabón de la cadena económica, facilitando los contratos a distancia y el pago instantáneo. ${ }^{6}$ Los proveedores de aplicaciones cobran

3 Ulloa Coelno, Fabio, Direito Civil. Parte Geral, Editora Saraiva, Sao Paulo, 2012, 5a Ed., p. 265.

4 Meinberg Ceroy, Frederico, "Os conceitos de provedores no Marco Civil da Internet", 2014, documento disponible en línea: http://www.migalhas.com.br/dePeso/16,MI211753,51045-Os+conce itos + de+ + provedores + no+Marco+Civil + da + Internet, 30 de enero de 2019.

${ }^{5}$ Lotufo, Renan. "Responsabilidade Civil na Internet", en Greco, M.; Martins, I. (Coords.), Direito e Internet: relações jurídicas na sociedade informatizada, Ed. Revista dos Tribunais, São Paulo, 2001, p. 212.

6 Lopes Matos, Inez, “A proteção do Consumidor Internacional no Comércio Eletrônico", Tesis de Maestría en Derecho, Universidad de São Paulo, Brasil, 2002, no publicada. 
importancia en esas relaciones jurídicas, pues intervienen de manera directa en tales actividades, al ser los proveedores de los datos generados en los diferentes negocios jurídicos que se realizan electrónicamente. Contribuyen así para que el consumidor sea a su vez un sub-proveedor de contenido, como ocurre en los blogs, por ejemplo, en donde el proveedor de la aplicación hospeda y ofrece servicios facilitadores para la creación o modificación del contenido.

Coincidiendo con SPARROw, podemos afirmar que el "networks"7 no es un fenómeno social nuevo, pues las personas ya mantenían redes para actividades comerciales antes del surgimiento de los medios electrónicos, aunque es un hecho que el alcance de las redes sociales electrónicas es significativamente más poderoso ahora.

El afianzamiento de las redes sociales en el mercado global está condicionado a la expansión global del número de participantes. Ello contribuye a que exista una mayor complejidad para determinar la responsabilidad civil contractual y extracontractual de los sujetos involucrados, cambiando el modo en que son vistas las relaciones jurídicas después de la propagación del internet. Hoy en día cualquier usuario puede ser al mismo tiempo consumidor, creador y destinatario de servicios o contenidos utilizando informaciones personales o de terceros.

\section{Desafios de las empresas de internet.}

Según Castell la mayoría de las empresas de comunicación del mundo siguen centradas en una perspectiva hacia el aspecto nacional o local, y cuestiona la definición de lo global: "no hay casi ningún grupo de comunicación verdaderamente global (...) Lo que es global son las redes que conectan la financiación, la producción y la distribución de los medios de comunicación dentro de cada país y entre países". ${ }^{8}$

Mientras las empresas multinacionales tradicionales generan riquezas a partir de la explotación del comercio de bienes y servicios en general, los gigantes de internet lo hacen a través de la comercialización de la comunicación, la información y los datos que poseen. Si bien esas empresas son creadas, modificadas, regidas y extinguidas según las leyes de un

\footnotetext{
7 Sparrow, Andrew, The Law of Virtual Worlds and Internet Social Networks, Gower Publishing Limited, Burlington, 2010, p. 235.

8 CAstells, Manuel, Comunicación y Poder, Alianza Editorial S.A., Madrid, 2011, p. 110.
} 
determinado Estado, las actividades que desempeñan están marcadas por el carácter extraterritorial e inmaterial del ciberespacio. ${ }^{9}$

Autores como HaRTLEY afirman que el estatuto personal de cada empresa o corporación es el instrumento que determina su creación, sus funciones, los atributos y facultades de los órganos que la componen, de sus directores y de sus accionistas que la conforman. La lex societatis es, por tanto, la identidad corporativa de las empresas y rige la vida interna de las sociedades empresariales, ${ }^{10}$ en cuanto a los derechos y deberes de los socios, la representación de la sociedad, la capacidad para realizar actos jurídicos, la responsabilidad de la empresa y de sus socios, así como respecto a su extensión. ${ }^{11}$

La economía digital, al menos en teoría, no modifica la manera en que son constituidas las empresas proveedoras de servicios de internet. En la sociedad internacional, cada Estado es soberano para establecer sus reglas para la constitución, modificación o extinción de la actividad empresarial. Así, las multinacionales deben observar las normas de cada país, acatando las disposiciones legales del lugar donde pretendan operar.

En el caso del derecho brasileño, el Código Civil del 10 de enero de 2002, establece en su artículo 985 que la sociedad adquiere personalidad jurídica con la inscripción en el registro propio correspondiente y en la forma que definen sus actos constitutivos.

La propia norma define en su artículo 1126 que será nacional la sociedad organizada de conformidad con la ley brasileña y que tenga en el país la sede de su administración. Por otro lado, la sociedad adquiere personalidad jurídica con la inscripción en el registro correspondiente ya sea el registro público mercantil o el registro civil de persona jurídica, cumpliendo las formalidades exigidas en el artículo 1150. Para las sociedades extranjeras no existen muchas diferencias, salvo que están sujetas además a la autorización del poder ejecutivo para su funcionamiento, aunque posean establecimientos en el territorio nacional (art 1134). En este sentido la lex societatis queda sujeta en la jurisdicción brasileña a la lex loci actus y a la lex loci contractus.

En el derecho internacional privado, la Ley de Introducción al Derecho

\footnotetext{
9 LÉvy, Pierre, Cibercultura, Editora 34 Ltda., São Paulo, 1999, p.199.

${ }^{10}$ Calvo, Alfonso; Carrascosa, Javier, Derecho internacional privado, Comares, Granada, 2014, $15^{\mathrm{a}}$ Edición, p. 677.

${ }^{11}$ Hartley, Trevor, "Mandatory rules in international contracts: the common law approach", Business regulation and consumer protection (Londres), 2010, vol. 59, p. 506.
} 
Brasileño de 1942, aún vigente, establece que las sociedades empresariales obedecen a las leyes del Estado en que se constituyen. Sin embargo, las filiales, agencias y sucursales, están sujetas a la aprobación de sus actividades por el poder ejecutivo, como se expresó anteriormente, destacándose que las empresas extranjeras quedan sujetas a la jurisdicción brasileña en cuanto a los actos de sus operaciones practicados en Brasil. ${ }^{12}$

Una vez autorizada a funcionar, la sociedad extranjera tomará el nombre que tenga en su país de origen, adicionando las palabras "de Brasil" o "para Brasil”. Además, la ley brasileña establece que el poder ejecutivo puede disponer condiciones idóneas para la defensa de los intereses nacionales al emitir su autorización. Entre los gigantes de internet que actúan en Brasil como proveedores de servicio de aplicaciones, podemos citar a: Google Brasil internet Ltda., Facebook Servicios Online de Brasil Ltda. y Yahoo! de Brasil internet Ltda.

Las violaciones cometidas en internet de las que resultan daños susceptibles de responsabilidad civil plantean una complejidad jurídica ante estas empresas, pues, por un lado, la jurisdicción brasileña se declara competente respecto a los actos que involucren a los gigantes de internet en Brasil; mientras que, por otro lado, estas empresas alegan estar sólo bajo la jurisdicción de Estados Unidos donde se encuentra su domicilio oficial. Cuestión que pone a prueba la efectividad jurídica de las decisiones judiciales emitidas en Brasil y que involucran a este sector. En este sentido, el derecho internacional regresa a uno de sus principios básicos, la cooperación jurídica internacional entre Estados, como vía de solución y ejecución de conflictos.

Asimismo, la Ley Marco Civil de Internet ${ }^{13}$ presenta una solución inteligente al disponer en su artículo 11 que: "En cualquier operación de recolección, almacenamiento, protección o tratamiento de registros, datos personales o de comunicaciones por proveedores de conexión y de aplicaciones de internet, en las que por lo menos uno de estos actos ocurra en territorio nacional, deberá ser obligatoriamente respetada la legislación brasileña, los derechos a la privacidad y a la protección de los datos personales y al secreto de las comunicaciones privadas y de los registros". Y

\footnotetext{
${ }^{12}$ Ley N $\mathrm{N}^{\circ} 4.657,1942$ (Brasil). Ley de introducción a las normas del derecho brasileiro, Artículo 11, $\S 1^{\circ}$, disponible en línea: http://www.planalto.gov.br/ccivil_03/decreto-lei/Del4657compilado.htm, 1 de agosto de 2018.

${ }^{13}$ Ley $\mathrm{N}^{\circ}$ 12.965, de 2014 (Brasil), Ley Marco Civil de Internet, disponible en línea: http://www. planalto.gov.br/ccivil_03/_ato2011-2014/2014/1ei/112965.htm, 20 de febrero de 2018.
} 
el número 2 del citado artículo obliga a las personas jurídicas domiciliadas en el exterior a someterse a las leyes brasileñas. ${ }^{14}$

La ausencia de un instrumento jurídico internacional que aborde los conflictos transfronterizos en el ámbito de internet, provoca serios problemas al momento de determinar la ley aplicable, la jurisdicción competente, y la ejecución y homologación efectiva de las sentencias extranjeras. Armonizar las reglas del derecho internacional privado permite garantizar seguridad y previsibilidad en las relaciones jurídicas internacionales, contribuyendo a una mayor efectividad en la extraterritorialidad de las decisiones judiciales que emanan de litigios en las sociedades actuales.

\section{DERECHO INTERNACIONAL PRIVADO E INTERNET}

\section{Elementos de conexión y solución de conflictos en el ciberespacio}

Las reglas del derecho internacional privado pueden ser utilizadas para resolver los conflictos transnacionales que ocurren en el espacio cibernético, pero la ausencia de normas internacionales hace que no sean claros los caminos a seguir. La incerteza sobre la ley aplicable a las relaciones privadas conectadas a múltiples sistemas jurídicos, el foro competente para juzgar litigios plurilocalizados y la eficacia de las sentencias emitidas por un país relacionadas a temas de internet, así como su homologación y reconocimiento en el extranjero, son algunos de los desafíos de esta rama del derecho.

De acuerdo con GoLDSCHMIDT en materia de jurisdicción internacional, rige en principio, la máxima de la generosidad. Así, cuantos más foros se pongan a disposición del actor, más cómodo le será realizar sus peticiones. Pero el despliegue de la generosidad supone, en primer lugar, que cada país tenga un derecho internacional privado justo y no permita la intervención desorbitada del orden público, pues, de lo contrario, el resultado del juicio dependerá decisivamente del derecho internacional privado del país a cuyos tribunales el actor acude, y esto provoca el fenómeno que los anglosajones denominan "forum shopping". ${ }^{15}$

En el espacio físico, el derecho internacional privado establece varios elementos de conexión que buscan soluciones adecuadas a las más diversas

\footnotetext{
${ }^{14}$ Ídem.

${ }^{15}$ Goldschmidt, Werner, Derecho internacional privado - Derecho de la tolerancia, Depalma, Buenos Aires, 1992, $8^{\text {a }}$ Ed.
} 
situaciones jurídicas. Elección de foro, domicilio del demandado, residencia habitual, nacionalidad, son algunos de los caminos que propone esta rama del derecho ante litigios transfronterizos, pero una vez que son llevados al ámbito del internet la situación resulta especialmente compleja, debido a la ubicuidad imperante en el medio.

La Unión Europea posee una de las normas más acabadas en cuestiones de derecho internacional privado, pero al igual que cualquier otro instrumento no cuenta con una diferenciación de tratamiento jurídico entre los casos en línea o en el mundo físico, los que son regulados por instrumentos generales como lo son el Reglamento de Bruselas I bis, ${ }^{16}$ Reglamento de Roma $I^{17}$ y Reglamento de Roma II, ${ }^{18}$ para determinar la ley aplicable y la jurisdicción competente. ${ }^{19}$ Vale apuntar el conflicto entre la Directiva Europea sobre Comercio Electrónico, ${ }^{20}$ que establece el principio del país de origen (que será la ley aplicable al lugar donde se ubica el local del establecimiento), y el Reglamento de Roma II, que establece como ley aplicable la del país donde ocurrió el daño (considerando 35). La regla de la Directiva ha influenciado indirectamente la ley aplicable para la solución de casos en internet, en el sistema de derecho internacional privado de la Unión Europea, complejizando las fuentes y dificultando con ello la determinación de la ley aplicable. Lo que, a criterio de De Sousa, obliga a que todas las cuestiones de responsabilidad civil en internet sean sometidas al Reglamento de Roma II y excluidas de la Directiva. ${ }^{21}$

En el panorama del Mercosur, no existe ninguna regla específica sobre ley aplicable y jurisdicción competente para casos de responsabilidad civil en internet. Solo se puede destacar el Protocolo de Buenos Aires sobre jurisdicción internacional en materia contractual, firmado el 5 de agosto de $1994,{ }^{22}$ el cual establece reglas sobre jurisdicción contenciosa internacional,

${ }^{16}$ Reglamento $N^{\circ}$ 1215/2012 del Parlamento Europeo y del Consejo de la Unión Europea, 2012 (Bruselas I bis).

${ }^{17}$ Reglamento No 593/2008 del Parlamento Europeo y del Consejo de la Unión Europea, 2008 (Roma I).

${ }^{18}$ Reglamento N 864/2007 del Parlamento Europeo y del Consejo de la Unión Europea, 2007 (Roma II).

${ }^{19}$ LutzI, Tobias, "Internet Cases in EU Private International Law - developing a Coherent Approach", International and Comparative Law Quarterly, 2017, Vol. 66 (3), p. 688.

${ }^{20}$ Directiva N²000/31/EC, del Parlamento Europeo y del Consejo de la Unión Europea, 2000.

${ }^{21}$ De Sousa Gonçalves, Anabela, "The Application of Rome II on the Internet Torts", Masaryk University Journal of Law and Technology, 2014, Vol. $8 \mathrm{~N}^{\circ} 1$, p. 39.

${ }_{22}^{2}$ Decreto Legislativo No 129, 5 de octubre de 1995 (Brasil); Decreto No 2.095, de 17 de diciembre de 1996 (Brasil). 
relativas a las obligaciones contractuales resultantes de las relaciones de consumo. Sin embargo, esta norma no se aplica a las cuestiones en internet, pues su promulgación es anterior a la popularización global del internet, no estando la norma enfocada a dicha materia.

Para determinar la responsabilidad civil en conflictos transnacionales en internet, la elección del foro muchas veces no puede ser determinada por los clásicos elementos de conexión como son el domicilio del demandado, la residencia habitual o la nacionalidad, debido a que no siempre es posible localizar el domicilio, residencia o nacionalidad del agresor.

El domicilio del demandado es un elemento que se trae del derecho civil clásico y se intenta adaptar al mundo virtual. La complejidad de determinar el domicilio legal del demandado va a depender de lo eficaz que resulten las leyes domésticas en establecer elementos de conexión, como lo son el $u r l$, el lenguaje del sitio, la moneda, el nombre de dominio, entre otros. En el caso de Brasil no existe una definición expresa de cuál de estos elementos debe ser utilizado para determinar el domicilio del demandado en internet, lo que dificulta la exigencia de la responsabilidad civil en estas cuestiones.

Por su parte, la residencia habitual en Brasil posee un papel protagónico, pues toda empresa extranjera para actuar es obligada a establecer un domicilio en el territorio brasileño, lo que necesariamente otorga supremacía jurídica a la residencia habitual, como elemento de conexión de las personas jurídicas vinculadas a las actividades en internet. El problema de esto es que los gigantes de internet solo reconocen la jurisdicción americana para dirimir sus conflictos, lo que dificulta cualquier equilibrio en la elección de foro y ley aplicable bajo los criterios del derecho internacional privado clásico.

Otro elemento cuestionable en el contexto digital es la nacionalidad. Si bien este ha ido perdiendo protagonismo en cuestiones de derecho civil transnacional para el espacio virtual, resulta de difícil aplicación ya que entrarían en juego varios criterios, todos con el mismo grado de ambigüedad, como lo son la nacionalidad del sitio web donde se cometió la violación, la nacionalidad del demandado y la nacionalidad del demandante. La nacionalidad del sitio web es en principio inaplicable, pues ciertamente su registro está vinculado por regla general a un país, pero en las legislaciones domésticas predomina el criterio que los proveedores de servicio, conexión o aplicación, no son responsables por las violaciones cometidas por terceros, como es el caso de la Ley Marco Civil de Internet en Brasil, que en su artículo 18, establece que los proveedores de conexión a internet no serán 
responsabilizados civilmente por los daños resultantes de los contenidos generados por terceros. ${ }^{23}$

Autores como DE Sousa ratifican que: "es a través de un acuerdo legal, fundamentado en el principio de la reciprocidad, que la competencia judicial en asuntos civiles podrá eliminar las distorsiones presentadas en el mercado global, obteniendo un equilibrio en la disparidad de los diversos sistemas existentes, simplificando así la solución de las controversias". ${ }^{24}$

OSTER, por su parte, propone que lo deseable del derecho internacional privado es el equilibrio adecuado entre derechos conflictivos, eficiencia, resistencia a los abusos y previsibilidad. En consonancia con ello SHEVILL propone que, en casos de violaciones transnacionales resultantes de transgresiones de los derechos de la personalidad en el ciberespacio, se realice un análisis para determinar el "centro de intereses", permitiendo establecer un justo equilibrio entre la libertad de expresión del demandado y los derechos de la personalidad del solicitante. ${ }^{25}$

Por lo tanto, vale la pena considerar la sustitución de la regla de publicación múltiple por una regla de publicación única, como se practica en los Estados Unidos. Una regla de publicación única implica que tendría jurisdicción sólo el Estado en que el editor inicialmente cargó la comunicación a un servidor web. Este enfoque (jurisdiccional) de "país de origen" tiene la ventaja de proporcionar un factor de conexión preciso que hace que las reivindicaciones jurisdiccionales sean previsibles. Sin embargo, dicho criterio es demasiado favorable para el demandado y susceptible de abuso, pues, en la práctica, los editores aprovechan las jurisdicciones que sean más favorables a la libertad de expresión, en detrimento de los derechos del demandante. Por lo anterior se concluye que la introducción de una norma de publicación única no es aconsejable. ${ }^{26}$

Resulta, pues, inminente reflexionar sobre las reglas del derecho internacional privado clássico, para resolver los litigios jurídicos transnacionales que resulten de las actividades en internet por parte de los usuarios o personas jurídicas involucradas. La ausencia de tratados

${ }^{23}$ Ley $\mathrm{N}^{\circ}$ 12.965, de 2014 (Brasil). Ley Marco Civil de Internet, disponible en línea: http://www. planalto.gov.br/ccivil_03/_ato2011-2014/2014/lei/112965.htm, 20 de febrero de 2018.

${ }^{24}$ De SousA, cit. (n. 21), p. 36.

${ }^{25}$ Oster, Jan, "Rethinking Shevill: Conceptualising the EU Private International Law of Internet Torts against Personality Rights", International Review of Law, Computers \& Technology, 2012, Vol. 26, pp. 113-128.

26 Ídem. 
internacionales al respecto obliga a la doctrina y a la jurisprudencia a establecer soluciones provisorias y ajustadas a la versatilidad de un medio en constante evolución tecnológica.

\section{JURISPRUDENCIA Y CONFLICTOS EN INTERNET}

En el ámbito internacional privado las cuestiones de violaciones cometidas en internet vienen siendo abordadas por los tribunales bajo dos perspectivas fundamentales, cuyo objetivo es minimizar el impacto de la multiplicidad de legislaciones y los conflictos de jurisdicción que de ello resulta.

La primera, llamada enfoque de localización, establece elementos de conexión que pueden ser localizados geográficamente, como el lugar de la actividad presuntamente delictiva o dolosa, el lugar donde se producen los efectos jurídicos de la violación o daño, y el lugar donde está domiciliado el infractor. La segunda, llamada enfoque de factores, busca que los tribunales determinen la jurisdicción aplicable sopesando una multiplicidad de factores, de manera que los países adopten una normativa única, o un pequeño número de normas comunes, para la solución de conflictos que surgen en el medio digital. ${ }^{27}$

Si bien el enfoque de localización no es una solución definitiva, se apoya en conceptos como los de residencia habitual y domicilio, que desde algunos años están siendo utilizados como elementos de conexión, para enfrentar los conflictos de jurisdicción en la Conferencia de Derecho Internacional Privado de La Haya para otros asuntos de carácter transnacional.

El establecimiento de este enfoque como solución definitiva no es aceptado por todos los países de la misma manera, ya que la localización del daño en internet tiende muchas veces a ser manipulada por los usuarios que cometen las violaciones. El infractor puede elegir el lugar desde el cual actúa, o el lugar donde se producirán los daños, provocando un verdadero fórum shopping, pues lo que se presente como violación en una jurisdicción no será necesariamente igual en otra.

Igualmente, el establecimiento de una jurisdicción única o la definición de un pequeño grupo de normas tampoco favorece la disminución de los conflictos generados en internet, ignorando que las violaciones cometidas en el

\footnotetext{
27 TRImble, Marketa, "The Multiplicity of Copyright Laws on the internet", Fordham Intellectual Property, Media and Entertainment Law Journal (Las Vegas), 2016, Vol. XXV, pp. 339-404.
} 
ambiente en línea muchas veces tienen impacto fuera de éste. Además, resulta de extrema complejidad que los países y actores de internet resuelvan someterse a una única jurisdicción o a solo un grupo reducido de ellos; pues las cuestiones de jurisdicción envuelven soberanía y territorialidad, principios definidos y establecidos en el ámbito internacional a lo largo de varios siglos. Salvo la Unión Europea, el resto de los países no poseen una adecuación normativa capaz de definir normas únicas para casos de responsabilidad civil en internet.

En la perspectiva de SOLER Y JIMÉNEZ debe seguirse la siguiente escala, para determinar la existencia de los contactos mínimos que habilitan para que una jurisdicción sea considerada adecuada ante un hecho susceptible de responsabilidad civil en internet: a) la jurisdicción personal es adecuada cuando el demandado contrata con los residentes de otra jurisdicción o estado; lo que presupone transmisión repetida de contenido entre los ordenadores a través de internet; b) la jurisdicción personal no es adecuada cuando el demandado solo ha publicado información en un sitio web pasivo, que está accesible a los usuarios de la jurisdicción extranjera; c) la jurisdicción personal no resulta clara para los sitios web interactivos donde los usuarios intercambian información y contenido con la página. ${ }^{28}$

En Estados Unidos la jurisprudencia ha optado por resolver cuestiones de responsabilidad civil en internet en base a dos casos importantes: el test Zippo y el test Calder. El test Zippo proviene del caso Zippo Mfg Co. v Zippo Dot Com. Inc. de 1996, en que la Corte de Pennsylvania estableció la jurisdicción en base al nivel de interactividad entre el sitio y el foro donde se reclamaba la protección, estableciendo que la jurisdicción personal es directamente proporcional a la naturaleza y a la calidad de la actividad comercial en internet. ${ }^{29}$

El test Calder proviene del caso Calder vs. Jones, de la Corte Suprema de Estados Unidos, de 1983. Se relaciona con la teoría de los efectos causados intencionalmente en el lugar donde tiene su jurisdicción el foro. Aquí no importa el nivel de interactividad del sitio como en el caso Zippo, sino dónde se producen los efectos jurídicos de la violación, lo que en el ámbito de internet resulta especialmente complejo dada la inmaterialidad propia del ambiente digital.

\footnotetext{
${ }^{28}$ Soler, Israel; Guillermo, William, “¿Como establecer la jurisdicción y competencia en casos de internet? Tendencias internacionales y nacionales", Diálogos de saberes, 2014, № 41, pp. 15-32.

${ }^{29}$ United States District Court for the Western District of Pennsylvania (EEUU), 16 de enero de 1997, 952 F. Supp.1119, disponible en línea: http://www.internetlibrary.com/pdf/Zippo-Manufacturing-ZipDot-Com-WD-Pa.pdf, 5 de septiembre de 2018.
} 
Autores como GeIsT, resaltan la necesidad de una conexión que permita definir vínculos de una determinada persona en internet con el sitio del foro; tales como el lenguaje específico, la moneda, la nacionalidad, el uso del dominio del país, la dirección de IP, etc. ${ }^{30}$ Tanto el caso Zippo como Calder han ganado adeptos en las diferentes jurisdicciones del mundo, siendo adaptados a las diversas realidades jurídicas.

El caso Yahoo! Inc. vs. Francia, de 2006, muestra la complejidad de la aplicación de los contactos mínimos para determinar la responsabilidad civil en internet. En ese entonces "Yahoo!" mantenía una serie de sitios web específicos con las cuestiones que interesan a cada país. Así, a finales de ese año, la justicia francesa ordenó que se prohibiera el acceso de los usuarios franceses, desde "Yahoo!", a un sitio de subasta sobre productos nazis; concediendo un plazo de tres meses para hacer efectiva la decisión judicial e imponiendo una multa por cada día sin implementar la orden.

En 2007 "Yahoo!" decidió apelar ante la jurisdicción francesa, alegando que esta orden era inaplicable en Estados Unidos, resultando el nuevo fallo favorable a "Yahoo!" En la perspectiva de GeITs, la decisión del tribunal francés está determinada por las tres capas de la teoría de los contactos mínimos. Esto confirma la importancia y el impacto a escala mundial de la jurisprudencia en las cuestiones de internet; debido a la ausencia de una normativa global que resuelva los litigios en la red. ${ }^{31}$

Brasil, por su parte, busca aplicar el criterio del centro principal de gravedad, como se evidencia en el Recurso Especial 1.168.547-RJ, del Tribunal Superior de Justicia (STJ, por sus siglas en portugués). ${ }^{32}$ Acá la empresa española utilizó la imagen de una persona para fines publicitarios sin su consentimiento, lo que generó que fuera ratificada la condena por violación a los derechos de la personalidad, incluyendo la privacidad y la imagen.

Aunque el contrato se firmó con cláusula de elección de foro en el exterior, el STJ entendió que la jurisdicción brasileña era competente con base en el artículo 88 del Código de Procedimiento Civil de 1973 vigente en la época del juicio, puesto que la autora tenía domicilio en Brasil.

A pesar de ser un caso anterior a la Ley Marco Civil de Internet, el

\footnotetext{
${ }^{30}$ GeIsT, Michael, "Is there a there there - toward greater certainty for internet jurisdiction", Berkeley Technology Law Journal, 2001, Vol. $16 \mathrm{n}^{\circ}$ 3, disponible en línea: http://scholarship.law.berkeley.edu/ cgi/viewcontent.cgi?article=1331\&context=btlj, 8 de diciembre 2018 .

${ }^{31}$ GeIsT, cit. (n. 30).

${ }^{32}$ Tribunal Superior de Justicia (Brasil), 11 de mayo de 2010, Recurso Especial 1.168.547-RJ (2007/0252908-3).
} 
tribunal concluyó que se produjo un uso indebido de la fotografía, debido a que la imagen de la persona fue utilizada sin su consentimiento en un sitio electrónico, anclado en el exterior, pero accesible por la web en cualquier lugar, aplicando así las reglas del mundo físico al espacio virtual.

La realidad jurídica existente en cuestiones de responsabilidad civil en internet provoca que sean cada vez más frecuentes la existencia de conflictos transnacionales. La ausencia de normas domésticas e internacionales ha provocado un incremento del protagonismo de la jurisprudencia en estos temas. La jurisprudencia americana ha cobrado protagonismo a escala global como uno de los principales referentes en el tema, lo que muestra la necesidad de una norma internacional que logre definir con mayor claridad el tratamiento para estas cuestiones.

\section{RESPONSABILIDAD CIVIL EN INTERNET: REALIDADES EN BRASIL}

Más de la mitad de la población en Brasil emplea como principal medio de comunicación y acceso a internet el celular. ${ }^{33}$ Esto propicia que las personas estén conectadas la mayor parte del tiempo de su vida, empleando esta vía de conexión para cuestiones diversas como trabajo, comercio, recreación, cultura, diversión, socialización e información. Este fenómeno provocó un incremento de actos ilícitos y criminales, que traspasan las fronteras políticas que conocemos y complejizan la manera en que es exigida la responsabilidad civil.

La responsabilidad civil en la red es uno de los grandes retos de la sociedad de la información. Para el derecho civil clásico la responsabilidad puede ser contractual o extracontractual. La primera surge ante el incumplimiento de una obligación por una de las partes de un contrato jurídico. La segunda es el resultado de daños causados por personas, ya sean naturales o jurídicas, que tienen una relación no contractual. En ambos supuestos, la ley impone una obligación de reparación de los perjuicios ocasionados o sufridos. Pero a nivel global no existe una norma que posibilite la cooperación jurídica internacional sobre el asunto.

La calificación del daño en las relaciones privadas en internet es

${ }^{33}$ En Brasil el celular es el principal medio de acceso $(92,1 \%$ de los domicilios acceden por este medio). AgENCIA BRASIL, "IBGE: celular se consolida como o principal meio de acesso à internet no Brasil", 2016, disponible en línea: http://agenciabrasil.ebc.com.br/geral/noticia/2016-12/ibge-celularse-consolida-como-o-principal-meio-de-acesso-internet-no-brasil, 22 de diciembre de 2018. 
facultad de los ordenamientos internos de cada Estado, lo que provoca variaciones considerables de un país a otro. Sumado a esto, la ausencia de un tratado multilateral o de una ley modelo que permita una aproximación top-down de las legislaciones, imposibilita establecer patrones mínimos para las actividades de proveedores de conexión y de aplicación en el ambiente virtual para un acercamiento legislativo bottom-up.

En este sentido, el derecho brasileño es bastante flexible y abierto al reconocer en su Código Civil un amplio universo de competencias a las autoridades brasileñas, con relación a los litigios transnacionales. Los artículos 21 y 22 de la referida norma posibilitan que el tribunal sea competente cuando el demandado, sin importar su nacionalidad, esté domiciliado en Brasil, cuando la obligación tenga que ser cumplida en Brasil o cuando el hecho haya ocurrido o bien, sea practicado en Brasil. ${ }^{34}$

En lo que respecta a la responsabilidad civil en el derecho brasileño, el acto de daño podrá ser lícito, ilícito o por riesgo. De acuerdo con el artículo 186 del Código Civil de 2002, aquél que, por acción u omisión voluntaria, negligencia o imprudencia viola derechos y causa daño a otros, aunque sean exclusivamente morales, comete acto ilícito. Además, el artículo 187, aplicable igualmente al espacio virtual, dispone que "comete acto ilícito el titular de un derecho que, al ejercerlo, excede manifiestamente los límites impuestos por su fin económico o social por la buena fe o por las buenas costumbres". El objetivo de la responsabilidad civil es "establecer situaciones avaladas por actos ilícitos por terceros, como elemento esencial para la vida en sociedad", ${ }^{35}$ imponiendo al causador del daño, la obligación de repararlo independientemente de la culpa, o bien cuando la actividad normalmente desarrollada por el autor del daño implica, por su naturaleza, riesgo para los derechos de otros, conforme al artículo 927.

Uno de los grandes avances del derecho brasileño fue la aprobación de la Ley $\mathrm{N}^{\circ} 12.965$ de 23 de abril de 2014, que establece reglas sobre responsabilidad civil por daños causados en internet. Conocida como Ley Marco Civil de Internet, establece principios, garantías de derechos para los usos de internet en Brasil, así como elementos de conexión para resolver los litigios resultantes de las actividades online. Lo que denota el amparo

\footnotetext{
${ }^{34}$ Ley N ${ }^{\circ}$ 10.406, 10 de enero de 2002 (Brasil). Código de Derecho Civil Brasileiro, Artículo 21 a 22, disponible en línea: http://www.planalto.gov.br/ccivil_03/leis/2002/L10406.htm, 1 de septiembre de 2018.

${ }^{35}$ DE BeSSA' Paulo, Dano ambiental: uma abordagem conceitual, Lumen Juris, Rio de Janeiro, 2000, p. 118.
} 
legislativo a los proveedores, en pos de la libertad de expresión y contrario a la censura previa. ${ }^{36}$

En esta lógica son aplicables las reglas generales de jurisdicción a las relaciones jurídicas transnacionales en internet, que involucren a los diferentes actores, como proveedores de conexión, de aplicación o de contenido y usuarios.

Como regla general se observa que las empresas extranjeras con domicilio en Brasil, como son proveedores de aplicación, intentan minimizar las competencias de los foros brasileños para examinar litigios que involucran derechos de la personalidad. En el caso del Recurso Especial $\mathrm{N}^{\circ}$ 370.46-Sp, Google Brasil Internet Ltda. alegó que era imposible cumplir la orden judicial brasileña que ordenó remitir el suministro de datos del responsable por la inserción de un determinado video en internet, porque tales informaciones estarían sobre la jurisdicción internacional de los Estados Unidos. El Tribunal Superior de Justicia determinó que el hecho de que el IP y otras informaciones sean de origen extranjera no limita la competencia judicial brasileña y no impide que las informaciones sean facilitadas por el proveedor de contenido. Además, el tribunal basó su decisión en el Decreto $\mathrm{N}^{\circ} 3810 / 2001$, que regula la cooperación internacional en materia penal, lo que no impide la competencia brasileña sobre el asunto. ${ }^{37} \mathrm{Se}$ debe advertir que esta norma es un tanto incompleta pues dispone en su artículo 11, que son las autoridades competentes indicadas en el Marco Civil las responsables de definir el fundamento legal aplicable para acceder a los datos registrados. Esta ambigüedad evidencia la falta de profundidad y dominio del tema por parte del legislador en cuestiones de sensibilidad extrema, pues de ello emanan los ilícitos civiles que devienen en exigencias de responsabilidad civil.

Si bien la Ley de Datos Personales, Ley No13.709 del 14 de agosto de 2018 , deja clara la importancia del respeto a la privacidad, libertad de expresión y autodeterminación informativa, entre otros principios, ello no concede libertad de manipulación de datos a las personas naturales o jurídicas de derecho público o privado que trabajen con datos personales. $\mathrm{Al}$ respecto el artículo 3 deja claro que, con independencia del país o la sede

36 Guimarães, Thiago, "Responsabilidade civil de provedores de conteúdo da internet", Revista Brasileira de Direito Civil (Rio de Janeiro), 2015, vol. 4. p. 98.

37 Tribunal Superior de Justicia (Brasil), 29 de agosto 2013, Recurso Especial N 370.461-SP $(2013 / 0206016-2)$ 
donde estén localizados los datos, y siempre que la operación o tratamiento sea realizada en territorio brasileño, compete a éste conocer y juzgar los asuntos relacionados al tema. ${ }^{38}$

El primer elemento de conexión referente a los actos jurídicos toma en consideración el lugar donde los proveedores de conexión y de aplicación ejercen sus actividades (locus regit actum). El capítulo II, "De los proveedores de conexión y de aplicación de internet", de la Ley Marco Civil de Internet, dispone en el artículo 11 que en cualquier operación, recolección, almacenamiento, guarda y tratamiento de registros de datos personales o de comunicaciones por proveedores de conexión y de aplicaciones de internet en que, al menos uno de esos actos ocurra en territorio nacional, deberá obligatoriamente respetarse la legislación brasileña y los derechos a la privacidad, protección de datos personales y secreto de las comunicaciones privadas y sus registros. En otras palabras, si una de las actividades enunciadas en la norma, ocurre en territorio brasileño, la ley aplicable será la brasileña. Considerando la inmaterialidad del internet y que el usuario también es productor de datos, la conexión con el derecho brasileño será siempre posible cuando se refiera a los actos de recolectar, guardar o tratar los datos personales. En el caso de daño, se aplica la ley brasileña en razón de la lex loci damni.

Con relación al segundo elemento de conexión, se toma en cuenta el lugar donde el bien mueble (terminal de comunicación) está situado (lex rei sitae), siendo aplicable la ley brasileña cuando por lo menos uno de los terminales (computador laptop, celular, tablet, entre otros) esté localizado en Brasil para la recolección de datos en territorio nacional y también para el contenido de las comunicaciones, conforme el párrafo 1 del artículo 11, de la Ley Marco Civil de Internet.

El tercer elemento de conexión se refiere a las personas jurídicas, estableciendo que también se aplica lo dispuesto en el citado artículo 11 sin importar que las actividades sean realizadas por personas jurídicas domiciliadas en el exterior. Siempre que oferten servicios al público brasileño le es aplicable la ley local, pues toda empresa extranjera debe al menos tener una sucursal o representación en territorio brasileño (lex societatis). ${ }^{39}$

\footnotetext{
${ }^{38}$ Ley N ${ }^{\circ}$ 13.709, 14 de agosto de 2018 (Brasil). Ley de Datos Personales, disponible en línea: http:// www.planalto.gov.br/ccivil_03/_Ato2015-2018/2018/Lei/L13709.htm, 6 de febrero de 2019.

39 Toda persona jurídica que ejerce actividades en Brasil, está obligada a tener domicilio legal o representación comercial dentro del territorio brasileño, y ser aprobado por el Poder Ejecutivo para su establecimiento. Ley No 10.406, 10 de enero de 2002 (Brasil). Código de Derecho Civil Brasileiro,
} 
Al mismo tiempo, la Ley Marco Civil de Internet impone a los proveedores de conexión y de aplicaciones de internet la obligación de ofrecer información que permita verificar el cumplimiento de la legislación brasileña sobre el almacenamiento o tratamiento de datos, en relación con el respeto a la privacidad y el secreto de las comunicaciones. Sin embargo, esta obligación, requiere mayor regulación para establecer procedimientos que permitan agilizar la determinación de las infracciones.

En este sentido, la responsabilidad civil por daños derivados del contenido generado por terceros queda definida en la Ley Marco Civil de Internet, que en su artículo 18 dispone que el proveedor de conexión a internet no es responsable civilmente por daños resultantes del contenido generado por terceros. En el caso de proveedores de aplicaciones, se dispone en el artículo 19 que, con el objetivo de asegurar la libertad de expresión e impedir la censura, el proveedor de aplicaciones de internet solamente podrá ser responsabilizado civilmente por daños resultantes del contenido generado por terceros sí después de orden judicial específica, no toma las providencias para que, en el ámbito de los límites técnicos de su servicio y dentro del plazo establecido, vuelva indisponible el contenido apuntado como infractor, reservando las disposiciones legales en contrario.

Es importante destacar que la Ley tiene como objetivo, de una parte, asegurar la libertad de expresión, comunicación y manifestación del pensamiento, e impedir la censura; y, de otro lado, proteger los derechos de personalidad, privacidad, de datos personales, garantizando la neutralidad de red y el respeto a los derechos humanos. Considerando la potencialidad de daños trasfronterizos y la soberanía de los Estados para legislar sobre la materia.

La aplicación de la lex fori, principio predominante en la jurisdicción brasileña, resulta muchas veces insuficiente para resolver los problemas que acontecen en el espacio virtual. Tanto la inmaterialidad como la transnacionalidad de las violaciones dificultan la ejecución efectiva de un marco civil, que pretende regular las relaciones en internet y que termina encontrando barreras jurídicas en la ejecución de decisiones judiciales que solo alcanza alguna solución a través de la cooperación jurídica internacional.

Si bien la legislación brasileña no es totalmente perfecta en cuanto a la protección sobre responsabilidad civil en cuestiones de actos ilícitos en

Artículo 45, disponible en línea: http://www.planalto.gov.br/ccivil_03/leis/2002/L10406.htm, 1 de septiembre de 2018. 
internet, al menos se aprecia una preocupación gubernamental de proteger cuestiones tan sensibles y complejas para el derecho internacional privado. La exclusividad que posee la jurisdicción brasileña para ser competente en materia de conflictos de ley abarca plenamente el ambiente de internet. El problema reside en cómo responsabilizar los casos en relación con el anonimato y el control de informaciones, cuando ellas circulan por otros medios electrónicos fuera del control de los proveedores de internet o de las empresas. Intercambios de terminal a terminal como bluetooth, continúan siendo el terreno apropiado para la ocurrencia de actos criminales o daños civiles. La utilización del principio de analogía entre el mundo físico y el virtual, si bien es la alternativa más empleada hasta el momento, tampoco resulta la solución definitiva cuando enfrentamos cuestiones de responsabilidad civil.

El derecho interno brasileño trabaja para hacer más claras las reglas sobre los problemas derivados de daños causados en el ciberespacio. Sin embargo, existe la necesidad de adoptar tratados internacionales con el fin de facilitar la cooperación jurídica internacional y el reconocimiento y ejecución de sentencias extranjeras sobre el asunto. Para esto, es importante que las reglas sobre competencia internacional también sean muy claras, para así contar con un mayor reconocimiento de las decisiones extranjeras, considerado uno de los elementos necesario para su eficacia extraterritorial.

\section{Responsabilidad civil contractual}

La responsabilidad civil es la obligación derivada de un deber jurídico de resarcir el daño creado. El tema de la responsabilidad civil contractual en internet presenta un problema adicional, pues, a diferencia de lo que ocurre en la vida física, la relación jurídica en el mundo virtual encuentra dos aristas contractuales: la referida a la información que es suministrada por la red (esto es, los bytes, que es lo que se transmite cuando guardamos una imagen, diseño, video, música, o un servicio en el computador); y otra referida a cuando la red fue simplemente el vehículo para formalizar un contrato, sirviendo como cualquier otro soporte.

El siglo XX fue marcado por el papel del consumidor internacional, transformándose en agente activo de las relaciones económicas transfronterizas. ${ }^{40}$ Anteriormente el consumo era marcado por el

${ }^{40}$ LOPES, cit. (n. 6). 
desplazamiento físico. Ya en el espacio virtual, existe una discusión sobre sí los proveedores de conexión y de aplicación son responsables por eventuales daños causados por los usuarios a los consumidores de sus servicios.

En el Código Civil brasileño de 2002 se establece que la libertad de contratar será ejercida en razón de los límites de la función social del contrato, así como la obligación del cumplimiento del principio de buena fe hasta la ejecución del contrato. ${ }^{41}$ Analizando los dos artículos correspondientes se observa que, si bien la legislación no es expresa sobre los contratos electrónicos, por analogía cabe deducir que nada prohíbe en la legislación local la aplicación de esta norma al contexto virtual para celebrar negocios jurídicos en este medio.

En la jurisdicción norteamericana, existen dos soluciones jurídicas a la hora de establecer elementos de conexión: el lugar donde se produce el daño o el lugar donde son visibles los efectos del daño. En la órbita contractual la jurisdicción muchas veces es decidida o pactada en el propio cuerpo del contrato. Cuando llevamos esta realidad al ambiente virtual que aún no cuenta con soluciones definitivas la complejidad es mayor... ¿Dónde se cumple un contrato celebrado a través de la red?

Si el medio virtual es solo la vía para pactar el contrato, las soluciones resultaran más viables ya que se aplicará la norma existente para los contratos físicos. El desafío surge cuando la ejecución y cumplimiento del contrato tiene lugar a través del medio virtual; ejemplo de ello es una descarga en la red, el almacenamiento de archivos e informaciones, el intercambio o almacenamiento de músicas, imágenes, textos, videos, etc. En la realidad, las partes conocen el servidor, sitio web o url, al que están suscritas o con el que contratan un servicio, pero probablemente no conocen la localización de dicho servidor y mucho menos el lugar donde pasará a ser objeto del contrato. ¿Dónde se cumple el contrato por la prestación de una descarga o una subida de archivos en internet? ¿Cómo exigir la responsabilidad civil ante un incumplimiento contractual de este tipo? ¿Cuál será la jurisdicción aplicable?

Normalmente las soluciones jurídicas en materia de conflictos o incumplimiento contractual están dadas por el establecimiento del lugar donde se produjo el daño, o por la aplicación de la legislación pactada en el

\footnotetext{
${ }^{41}$ Ley N ${ }^{\circ} 10.406,10$ de enero de 2002 (Brasil). Código de Derecho Civil Brasileiro, Artículo 421-422, disponible en línea: http://www.planalto.gov.br/ccivil_03/leis/2002/L10406.htm, 1 de septiembre de 2018.
} 
contrato. Sin embargo, en una transmisión que solo ocurre en el ámbito de internet y donde las informaciones circulan en el medio online por varias jurisdicciones al mismo tiempo, es preciso establecer o definir cuál sería la legislación aplicable. De ahí que la solución que ofrece la legislación brasileña en el sentido de someter a los gigantes de internet a la jurisdicción local resulta una salida razonable para la reparación de los daños causados a personas naturales o jurídicas en territorio brasileño.

La Ley Marco Civil de Internet establece como derecho y garantía de los usuarios la aplicación de normas de defensa del consumidor en las relaciones de consumo realizadas en internet. Con todo, debe existir un equilibrio en las relaciones entre proveedores de acceso y de contenido y los derechos y garantías del consumidor, como ya abordamos con anterioridad en sus artículos 18 y 19.

Anterior a la vigencia de esta ley, el STJ, ya había decidido la obligación de los proveedores de aplicaciones o de contenido de regirse por el Código de Defensa del Consumidor (CDC). El STJ manifestó: "que el hecho de que el servicio sea prestado por el proveedor de servicios de internet de manera gratuita no desvirtúa la relación de consumo, pues el término "mediante remuneración" utilizado en el artículo 3, apartado 2 del $\mathrm{CDC}$, debe ser interpretado de la forma más amplia, a modo de incluir la ganancia indirecta del proveedor". ${ }^{42}$

En el caso del Recurso Especial 1.316.921 de RJ, el tribunal determinó la responsabilidad de Google de excluir determinadas imágenes de los resultados de búsqueda de su sitio web, independientemente de la indicación de los url de las páginas de providencia de las imágenes. Google, en respuesta al recurso especial, alegó la imposibilidad de realizar el monitoreo de todo el contenido indicado como resultado de su herramienta de búsqueda. Además, sostuvo en su defensa que el cumplimiento de esa medida llevaría a la censura previa de contenido. ${ }^{43} \mathrm{Su}$ defensa fue acogida por el tribunal dando lugar al recurso, por entender descabellado imponer a los proveedores de búsquedas, considerando especies de género del proveedor de contenido, cualquier restricción de las búsquedas en sus sistemas.

Desde la perspectiva de los derechos fundamentales, la Constitución Federal asegura la libertad de expresión, los derechos del consumidor, la

\footnotetext{
${ }^{42}$ Tribunal Superior de Justicia (Brasil), 26 de junio de 2012, Recurso Especial 1.316.921 - RJ (2011/0307909-6).

${ }^{43}$ Ídem
} 
inviolabilidad de la intimidad, de la vida privada, de la honra y de la imagen de las personas, asegurando los derechos a la indemnización por los daños materiales o morales resultantes de su violación y garantizando el derecho a la propiedad, que debe atender a su función social. Se agrega a la disposición constitucional, que la manifestación del pensamiento, la creación, la expresión y la información, de cualquier forma, proceso o vehículo no sufrirán restricción alguna. Por su parte el Código Civil brasileño dispone, que la libertad de contratar será ejercida en razón y dentro de los límites de la función social del contrato, ${ }^{44}$ lo que determina que no exista impedimento en cuanto a la equiparación del contrato físico al virtual.

En el caso de las relaciones jurídicas internacionales que ocurren en internet, involucrando a proveedores de conexión o de aplicación con sus usuarios, el tribunal brasileño posee competencia para decidir sobre el asunto según los términos del artículo 21 del Código de Proceso Civil, cuando el demandado, ${ }^{45}$ cualquiera que sea su nacionalidad, esté domiciliado en Brasil; ${ }^{46}$ cuando la obligación deba cumplirse en Brasil; y cuando el hecho o el acto haya ocurrido o fue practicado en Brasil. En el mismo sentido, el artículo 22 de la citada norma también establece como jurisdicción competente aquellas referentes a las relaciones de consumo transfronterizas.

De este modo, la autoridad judicial brasileña es competente para dirimir los litigios derivados de daños por incumplimiento de obligaciones contractuales, en cuanto a los daños causados por la propia persona o por terceros en razón del contenido publicado en el espacio virtual (fórum damni o forrum delicti commissi). El contenido puede implicar ofensas a diversos derechos como los de la personalidad, privacidad, datos personales o de propiedad intelectual.

Las relaciones privadas internacionales entre usuarios y prestadores de servicios de aplicación de contenido, han sido objeto de procesos judiciales ante los tribunales brasileños. En uno de los primeros casos ante el Tribunal Superior de Justicia, Sentencia 784-DF, "Google Brasil"

\footnotetext{
${ }^{44}$ Ley N ${ }^{\circ}$ 10.406, 10 de enero de 2002 (Brasil). Código de Derecho Civil Brasileiro, Artículo 421, disponible en línea: http://www.planalto.gov.br/ccivil_03/leis/2002/L10406.htm, 1 de septiembre de 2018.

${ }^{45}$ La interpretación del demandado alcanza tanto las personas naturales como jurídicas. Así, el párrafo único del artículo 21 dice que se considera domiciliada en Brasil las personas jurídicas extranjera que en ella tenga agencia, filial o sucursal.

${ }^{46}$ Estas hipótesis son las mismas que contiene el Código de Proceso Civil brasileño, previstas en su Artículo 88. Ley № 13.105, 2015 (Brasil), Código de Proceso Civil, disponible en línea: http:// www.planalto.gov.br/ccivil_03/_ato2015-2018/2015/lei/113105.htm, 10 de agosto de 2018.
} 
alegó la supuesta imposibilidad de cumplir la orden de ruptura del secreto de las comunicaciones, hechas por el investigado a través de Gmail, y que los datos en cuestión estaban almacenados en territorio norteamericano. Alegando que la empresa controladora de "Google Inc.", domiciliada en Estados Unidos, era quien de hecho almacenaba los datos de e-mail y sms, que serían inaccesibles física y jurídicamente para la sucursal en Brasil. La sala especial del tribunal, decidió por mayoría sobre la cuestión de orden presentada por la jueza encargada del caso, que la empresa situada en Brasil se somete obligatoriamente a las leyes brasileñas, bien con el plazo cumplido de la orden del sigilo telemático emitida, so pena de multa diaria. ${ }^{47}$

En el caso del Recurso Especial 370.461-SP, presentado ante el Tribunal Superior de Justicia, "Google Brasil Internet Ltda.", alegó no ser responsable por incumplir la orden judicial que determinó el suministro de datos por el responsable de insertar el video indicado por el "Banco Opportunity S.A.”, sobre jurisdicción internacional, proveniente de los Estados Unidos, en respeto a la soberanía, límites de la jurisdicción y de los efectos de la orden judicial brasileña. El tribunal aseveró que la justificación no prospera y que el hecho de que el IP y otras informaciones tengan origen extranjero no aparta la competencia jurisdiccional brasileña y no impide que las informaciones sean dadas. Además, el Decreto 3.820/2001 aborda la cooperación jurídica para materia penal, no siendo obstáculo para el tipo de informaciones solicitada. ${ }^{48}$

En el caso del Recurso Especial 733.830-SP, el STJ rechazó el pedido presentado por "Terra Networks Brasil S.A.", contra la decisión del tribunal que la condenó a indemnizar a la autora Eliana Cristina D. K. Bruno. A pesar de no haber producido el reportaje, las imágenes utilizadas eran de la autora y fueron divulgadas en el sitio de manera comercial, sin su autorización. En el juicio, el STJ subrayó que la empresa que pretende traer a Brasil un servicio estructurado en nuevas tecnologías, y con el alcance que posee internet, debe preocuparse de garantizar la seguridad de dicho sistema, no pudiendo imputar al consumidor la carga de buscar en el extranjero, y en legislación foránea, las garantías para la protección de sus derechos, debiendo la empresa responsable del servicio, en Brasil, asumir la

\footnotetext{
${ }^{47}$ Tribunal Superior de Justicia (Brasil), 17 de abril de 2013, Recurso Especial 784. DF- (2012. 0107506-0).

${ }_{48}$ Tribunal Superior de Justicia (Brasil), 29 de agosto de 2013, Recurso Especial 370461-SP (2013/0206016-2).
} 
total responsabilidad, sin perjuicio que la empresa puede exigir el derecho de retorno y de resarcimiento de acuerdo con las normas de sus contratos internacionales.

El entendimiento de los tribunales brasileños es que los proveedores de contenido tienen el deber de remover los mensajes, imágenes o propaganda consideradas ilegales u ofensivas. Todavía persiste la condicionante que debe ser indicado el url de la página en que está insertado el contenido ofensivo o ilícito, de manera que siendo confirmadas las alegaciones, sean excluidos definitivamente aquellos contenidos o, teniéndolas por infundadas, reestablezca su libre acceso, so pena de responder solidariamente con el autor directo del daño en virtud de la omisión practicada. ${ }^{49}$

Considerando que las empresas extranjeras se someten a las leyes y a los tribunales brasileños, la decisión tiene aplicación en todo el territorio nacional, por tanto, cuando los daños sean transfronterizos, habrá dificultades para la efectividad extraterritorial de la decisión, pues depende del reconocimiento del Estado extranjero para garantizar su ejecución.

2. Responsabilidad civil extracontractual: protección de datos y derechos de la personalidad.

\subsection{Protección de datos}

Para el análisis de las cuestiones que terminan exigiendoresponsabilidad civil extracontractual en internet, decidimos hacer un especial énfasis a dos líneas fundamentales: la protección de los datos personales y la protección de los derechos de la personalidad, debido a la amplitud de asuntos del derecho civil que son susceptibles de violaciones en la red.

El fenómeno de la globalización ha propiciado el desarrollo de las nuevas tecnologías, trayendo grandes ventajas a la sociedad y enormes desafíos. La conexión de usuarios en todo el mundo ha dispersado el espacio donde se almacenan nuestros datos.

Con el desarrollo de la informática se ha buscado dar mayor seguridad a la protección de los derechos a la privacidad y la inviolabilidad de los datos personales que resultan de la actividad del individuo en su día a día en internet. El control y la vigilancia ejercida, tanto por los Estados como por las grandes empresas de internet y su automatización, ha generado lo que la

\footnotetext{
49 Tribunal Superior de Justicia (Brasil), 13 de diciembre de 2013, Recurso Especial 1328706 -MG
} (2012/0122546-0). 
doctrina internacional reconoce como Big Data, o gran masa de datos.

Las primeras definiciones sobre los datos personales en internet provienen de la jurisprudencia europea en el caso Lindquist, aquí el tribunal europeo decidió que el nombre de las personas, su número de teléfono, información sobre su trabajo, hobbies, gustos y preferencias constituyen datos personales. ${ }^{50}$

Con el desarrollo de los estudios sobre datos personales encontramos dos categorías: datos sensibles y datos anónimos. Los primeros se refieren a datos cuyo almacenamiento, procesamiento y circulación puede provocar situaciones de discriminación, pues reseñan a cuestiones raciales, de salud, de vida sexual y de condiciones penales. ${ }^{51}$

Autores como Laura SCHERTEL refieren que los datos anónimos son provenientes de personas indeterminadas y pueden ser utilizados para fines estadísticos, pues su finalidad acaba protegiendo a las personas a través del anonimato. ${ }^{52} \mathrm{La}$ ausencia de legislación nacional al respecto apunta que tal definición es inspirada en la jurisprudencia europea y la legislación existente al respecto.

El desarrollo de la web a nivel internacional provocó un incremento en la circulación de informaciones a escala global. Este nuevo escenario fue propicio para la elaboración de nuevos bienes y servicios a través de internet, aumentando el número de datos y su almacenamiento y comercialización, surgiendo así conceptos como Big Data. Millones de consumidores dejan a su paso por la web rastros digitales, que son convertidos en datos que pasan a formar parte de la gran masa de datos que hoy poseen los gigantes de internet. Si bien el término es proveniente de la astronomía, este acabó migrando para la informática y el derecho y adoptando la definición de esa gran masa de datos que hoy es generado por todo usuario que navega en la red. Thomas DAVENPORT afirma:

"Big Data es un término genérico para los datos que no pueden ser contenidos en los repositorios usuales; se refiere a datos demasiado voluminosos para ser almacenados en un único servidor; poco estructurados para estar

\footnotetext{
${ }^{50}$ LaUdati, Laraine, Summaries of EU Court Decisions Relating to data Protection 2000-2015, OLAF European Anti-Fraud Office, 2016, documento disponible en línea: https://ec.europa.eu/anti-fraud/ sites/antifraud/files/caselaw_2001_2015_en.pdf, 4 de agosto de 2018.

51 Ibid., p. 24.

52 Schertel, Laura, Privacidade, proteção de dados e defesa do consumidor: linhas gerais de um novo direito fundamental, Saraiva, São Paulo, 2014, p.181-182.
} 
adecuados a un banco de datos en líneas y columnas, es muy fluido para un almacenamiento estático. Aunque el concepto hace referencia a su tamaño, en verdad el aspecto más complicado es su falta de estructura". ${ }^{53}$

Si los datos electrónicos están disponibles en cualquier lugar, ¿Se podría hablar de territorialidad como elemento de conexión ante violaciones de derechos sobre datos personales? Ciertamente no, pues la ausencia de Tratados Internacionales sobre protección de datos personales en el espacio internacional deja a los usuarios de internet desprotegidos y a merced de las políticas o contratos de adhesión que establecen gigantes de internet como Google o Facebook, los que no facilitan a sus usuarios información básica sobre su política de privacidad y censura.

En el caso de Brasil, la Constitución de 1988 consolida el principio de la dignidad humana en su artículo $1^{\circ}$, III, en el que es posible vislumbrar el tratamiento de la protección de la personalidad. En el artículo $5^{\circ}$ incisos X, XII y LXXII, se destaca la previsión del habeas data como remedio constitucional que busca garantizar al individuo el acceso a la rectificación de sus datos personales que consten en bancos de datos de carácter público.

Otra norma que aborda someramente el asunto es la Ley de Acceso a la Información en Brasil, ${ }^{54}$ que dispone los procedimientos a cumplir por parte de los Estados y municipios de Brasil, para garantizar el acceso a información, según lo previsto en el artículo 5 inciso XXXIII, artículo 37.2 y 216 de la Constitución Federal de 1988. Esta norma destaca que el tratamiento de los datos personales debe ser en equilibrio con el acceso a la información, a fin de garantizar este derecho fundamental, artículo 3. Por su parte el artículo 31, dispone que el tratamiento de los datos personales debe hacerse de forma transparente, con respeto a la intimidad, vida privada, honra e imagen de las personas, y en consonancia con las libertades y garantías individuales. Un aspecto interesante de este propio artículo, es que no podrá ser invocada la restricción de acceso a la información relativa a la vida privada, cuando el objetivo es perjudicar el proceso de irregularidades en las informaciones.

En cuanto al tratamiento de informaciones personales, la Ley del

${ }^{53}$ DAVENPORT, Thomas, Big data no trabalho: derrubando mitos e descobrindo oportunidades, Elsevier, Rio de Janeiro, 2014.

${ }^{54}$ Ley $N^{\circ} 12.527,2011$ (Brasil). 
Registro Positivo ${ }^{55}$ se dispone en su artículo 3 párrafo $3^{\circ}$ la prohibición de anotaciones relacionadas a informaciones sensibles como el origen social, ${ }^{56}$ la etnia, la salud, las fichas genéticas, la orientación sexual, y las convicciones políticas, religiosas y filosóficas. Además, el Código de Protección y Defensa del Consumidor ${ }^{57}$ instituye en el artículo 43 párrafo $2^{\circ}$ cuestiones relativas a la apertura del registro de datos personales y de consumo debe ser comunicada por escrito al consumidor, cuando no son solicitados por él. ${ }^{58}$

En cuanto a la protección de datos personales, es importante resaltar el caso Phorm Brasil, donde fue dispuesto por el Departamento de Protección y Defensa del Consumidor, vinculado al Ministerio de Justicia, imponer una multa de 3,5 millones de reales por monitorear la navegación de los consumidores en internet, para posteriormente comercializar sus datos, ${ }^{59}$ convirtiéndose una práctica habitual en el ambiente virtual.

Por otro lado, el Proyecto de ley PL 5344/2013, presentado ante la Cámara de Diputados de Brasil ${ }^{60}$ dispone en su artículo 4 que los derechos, obligacionesy responsabilidades civily penal sobre el contenido o definiciones en cuanto a su acceso, alteración o cualquier forma de tratamiento del mismo, que sean objeto de almacenamiento, custodia y depósito, pertenecen y son exclusivas del depositante, incluyendo su explotación económica. Así también el artículo 5 dispone que salvo disposición en contrario establecida en contrato, la restitución del contenido objeto del almacenamiento, la custodia y el depósito, en forma de computación en nube, debe darse en el lugar en que se celebre el contrato, conforme se contrate, corriendo los gastos por cuenta del solicitante.

\subsection{Derechos de la personalidad.}

Internet trae un gran desafío para las normas de derecho internacional

\footnotetext{
${ }^{55}$ Ley $\mathrm{N}^{\circ}$ 12.414, 2011 (Brasil).

56 Ídem.

${ }^{57}$ Ley N 8.078, 1990 (Brasil). Código de Protección y Defensa del Consumidor, http://www.planalto. gov.br, 20 de febrero de 2018.

58 Ídem.

${ }^{59}$ Departamento de Protección y Defensa del Consumidor(Brasil), Despacho No 137/2014/SENACON/ GAB, 22 de julio de 2014, disponible en línea: http:/www.telesintese.com.br/mj-multa-oi-em-r-35milhoes-por - monitorar-navegacao-de-clientes-banda-larga, 30 de agosto de 2018.

${ }^{60}$ Cámara de Diputados de Brasil, Proyecto de Ley PL 5344/2013, 9 de abril de 2013, disponible en línea: https://www.camara.leg.br/proposicoesWeb/fichadetramitacao?idProposicao=570970.
} 
privado relativas a los derechos de personalidad y a la libertad de expresión, pues provocan divergencias y conflictos entre estos dos derechos fundamentales. Corresponde al derecho internacional privado buscar soluciones que establezcan estándares mínimos, con el fin de circular decisiones al respecto que se dan en el ámbito transnacional.

El intercambio de información en el mundo virtual es intenso e instantáneo. A través de las redes sociales, una persona es capaz de interactuar directa e indirectamente con muchas otras, influenciando hábitos, costumbres, gustos e intereses. Este intercambio a niveles elevados es lo que se conoce como efecto viral, donde son compartidos o divulgados, imágenes, videos, escritos, etc.

Por lo tanto, una imagen o vídeo publicado en internet, dependiendo de su contenido, puede ser viralizada sin el control del primer usuario que la colocó en la web. Este efecto viral puede provocar violaciones a los derechos de la personalidad y entre ellos la imagen como el elemento más vulnerable. El caso Nissim Ourfali vs. Google ${ }^{61}$ fue juzgado por el Tribunal de Justicia de Sao Pablo el 15 de marzo de 2016 y se determinó que "Google Brasil" excluyera de internet los videos del demandante. La entrada realizada por su padre en la red social "YouTube", para mostrar a su familia un video de su cumpleaños de 13 años, el Bar Mitzvah, ceremonia que marca la mayoría de edad religiosa de los judíos del sexo masculino, utilizando una parodia musical famosa en la época, acabó provocando efectos negativos en una relación jurídica extracontractual, considerándose como un tercero perjudicado. ${ }^{6}$ Para la $9^{\text {a }}$ Cámara de Derecho Privado, los proveedores de contenido están obligados a borrar informaciones perjudiciales a la imagen de menores de edad, aunque la parte no indique la dirección de las páginas. ${ }^{63}$

Es importante recordar que la actividad realizada por el padre es compatible con los primeros objetivos de la red social. "Youtube", al principio, surgió como una red que facilitaba el intercambio de videos, debido a la imposibilidad tecnológica en esta época para intercambiar videos

${ }^{61}$ El Caso de Nissim Ourfali, trata sobre un niño judío que alcanza la mayoría de edad y con motivo de esta celebración sus padres filman un video que es colocado en YouTube para que la familia desde el otro lado del planeta, tuviera participación en tan importante evento religioso. El video se alcanza a viralizar y el niño sufre bullying en internet.

${ }^{62}$ Conjur, "Google deve retirar da internet vídeo de Nissim Ourfali”, http://www.conjur.com.br/2012out-27/justica-determina-quegoogle-retire-internet-video-nissim-ourfali\#top, 30 de agosto de 2018.

${ }^{63}$ Conjur, "Google é obrigado a excluir todos os vídeos de Nissim Ourfali do YouTube", httpp://www. conjur.com.br/2016-mar-15/google-obrigado-excluir-videos-nissim-ourfali-youtube, 20 de febrero de 2018. 
e imágenes de mayor peso a través de "Gmail", "Yahoo!", "Hotmail”, etc. E1 progreso tecnológico que venía sucediendo en este tiempo y la llegada de la cámara digital al contexto familiar, modificó el concepto de "foto familiar" y con ello el aumento de fotos y videos personales en la web.

En el caso Nissim Ourfali, sabemos que actualmente existe la posibilidad de subir el vídeo en modo privado, con acceso limitado a ciertos usuarios. ¿Esta información fue aclarada en el momento en que el padre de Nissim había cargado el vídeo en la red Youtube? Ningún gigante de internet tiene interés en controlar el efecto viral de los usuarios en la red, pues de ellos provienen ciertas ventajas y beneficios a quien coloca en estos sitios videos, fotos o mensajes que acaban teniendo un impacto transnacional.

En consonancia con lo anterior, la Ley Marco Civil de Internet resalta, en su artículo 21, la responsabilidad subsidiaria a los proveedores de aplicación, cualquiera que sea la situación que resulte de la divulgación sin autorización de sus participantes de imágenes, videos u otros materiales. ${ }^{64}$

En consecuencia, los hechos y actos practicados por las personas en el espacio virtual pueden tener efectos globales. El fenómeno de la viralización posibilita que cualquier persona pueda tener su momento de fama a nivel nacional y global, teniendo en cuenta la popularidad de la persona, el hecho y la circunstancia de cada caso. Los efectos negativos de la información (contenido erróneo, no autorizado por el autor, entre otros) pueden causar daños a los derechos de personalidad y de su privacidad.

Otro caso interesante es el de Casa del Autista vs. MTV, que ocurrió de la misma manera que el anterior, pues el vídeo se vio virtualmente en internet, haciendo una crítica a las personas que poseen dicha condición, lo que provocó las quejas y el repudio de los familiares y personas que la viven. El video se encuentra aún disponible en "Youtube", a pesar de que la sentencia del STJ dispone su retirada. En la realidad jurídica sucede que los gigantes de internet terminan no cumpliendo con los mandatos judiciales, evitando de una u otra forma su responsabilidad civil ante violaciones como el derecho a la imagen de personas que sufren determinadas condiciones o enfermedades y que pueden ser afectadas por el bullying, transmitido en un programa de televisión y vendido en internet.

En este tipo de hechos, es común que los referidos gigantes de internet evadan sus responsabilidades amparadas en las justificaciones técnicas.

\footnotetext{
${ }^{64}$ Ley No 12.965, 2014 (Brasil). Ley Marco Civil de Internet, disponible en línea: http://www.planalto. gov.br/, 20 de febrero de 2018.
} 
Ciertamente en la jurisprudencia brasileña existe un consenso común en relación a la responsabilidad de estos gigantes de internet respecto a las violaciones cometidas por terceros, en la mayoría de los casos manifiestan que resulta imposible retirar el vídeo del aire, ya que no son responsables de la colocación del mismo a disposición de todos los usuarios de la red.

Otro caso interesante fue el crimen de injuria practicado por un ex novio a su anterior novia en las redes sociales. El STJ entendió que corresponde a la justicia del estado procesar y juzgar los crímenes de injurias practicados a través de la red mundial de computadoras, aunque en páginas electrónicas internacionales, tales como las redes sociales Orkut y Twitter. Se ha comprobado que el simple hecho de que el supuesto delito ha sido cometido por internet no atrae por sí mismo la competencia de la Justicia Federal. Se destacó que la conducta delictiva de mensajes de carácter ofensivo, publicados por el ex novio de la víctima en las mencionadas redes sociales, no se subsume en ninguna de las hipótesis enumeradas en el artículo 109, IV y V, de la Constitución Federal. El delito de injuria no está previsto en algún tratado o convención internacional en el que Brasil se haya comprometido a combatir, como sí es el caso de los delitos de racismo, xenofobia o publicación de pornografía infantil, entre otros. Además, los mensajes vinculados en internet no ofendieron bienes, intereses o servicios de la Unión o de sus entidades autárquicas o empresas públicas. De esta forma, se declaró competente para conocer y juzgar el hecho, al Juzgado Especial Civil y Criminal. ${ }^{65}$

Las soluciones que proporcionan hoy los gigantes de internet en el ciberespacio se enfocan sólo en el caso a caso, y no en buscar un consenso global para actos ilícitos que generan responsabilidad civil. Las violaciones a los derechos de la personalidad, llevan la peor parte, pues una vez practicadas en el ambiente virtual muchas veces los obstáculos técnicos vuelven irreparable el daño causado. Más allá de la solicitud de la indemnización moral de la víctima, los países deben buscar una solución técnica definitiva que consiga minimizar la permanencia en la red de hechos que vulneren los derechos de la personalidad de forma indefinida.

Soluciones acogidas por Google como el caso de Orkut y los crímenes relacionados a pornografía infantil, deben ser extendidas a otras violaciones que suceden en internet. Google fue parte del compromiso social de la empresa

${ }^{65}$ Tribunal Superior de Justicia (Brasil), 11 de abril de 2012, Recurso Especial 12.5916 -RJ. (2012/0257814-0). 
moderna con la sociedad, bajo el mandato de la excelencia de los servicios que presta y de la merecida admiración con que cuenta en todo el mundo, actuando de forma decisiva para excluir páginas e identificar a los gánsteres virtuales. La ausencia de medidas definitivas en el ámbito internacional privado provoca una situación de vulnerabilidad de las personas, objetos de violaciones de derechos de la personalidad, aumentando sus angustias, impotencias y desconfianza en las soluciones jurídicas.

La jurisprudencia brasileña sostiene una posición que acaba beneficiando a los gigantes de internet en detrimento de los usuarios que sufren violaciones en la red. En el Recurso Especial 690.123-MG, el tribunal de primera instancia resolvió la acción de obligación de hacer interpuesta por la Dirección de Transporte y Logística S.A. contra Facebook Servicios Online de Brasil Ltda., para establecer la exclusión de perfiles en las redes sociales. En este caso, el magistrado decidió que los proveedores de servicios de internet sólo son responsables de los daños causados a terceros derivados de actos ilícitos practicados por sus usuarios, si se les notifica acerca del contenido divulgado y permanecen inertes, no retirando de la red las informaciones lesivas. ${ }^{66}$

La complejidad de las exigencias de la responsabilidad civil derivada de las violaciones de internet está determinada por leyes sustantivas de alcance territorial, que no corresponden con la ubicuidad de la red. La aplicación de normas de derecho sustantivo resulta muy difícil, pues cada país establece su sistema de normas, valores y cultura jurídica en general. Es un poco surrealista pretender cierta armonización en lo referente a la responsabilidad civil extracontractual, pues la efectividad de las decisiones judiciales dependerá del nivel de impacto que tenga en el país que decide o que necesita cumplir la decisión.

La justicia brasileña siempre es competente para conocer de los asuntos que generan responsabilidad civil en la internet. El cierre de la legislación local en lo relativo a los elementos de conexión, posee un punto positivo si lo comparamos con realidades foráneas que establecen cuestiones de forum shopping, jurisdicción personal o fórum no conveniente. La verdadera problemática es la ejecución extraterritorial de decisiones que traspasan la realidad facto-jurídica del territorio brasileño. Es la jurisdicción clara en cuanto a la definición de elementos de conexión, y poco objetiva en

\footnotetext{
${ }^{66}$ Tribunal Superior de Justicia (Brasil), 30 de junio de 2015, Recurso Especial 690.123-MG (2015/0069500-8).
} 
cuanto a la manera en que serán ejecutadas las decisiones, que envuelven cooperación jurídica internacional y ejecución de sentencias extranjeras. ¿Será el elemento de conexión la piedra angular de la solución de conflictos en internet? Es un camino de difícil definición y solución definitiva. La tecnología pone a prueba constantemente la efectividad del derecho, en cuanto al sistema de normas que busca regular las conductas humanas en la sociedad.

\section{CONCLUSION. COMENTARIOS FINALES.}

La responsabilidad civil transnacional por daños es uno de los grandes desafíos de la sociedad globalizada, frente a la ausencia de tratados internacionales que unifiquen las reglas del derecho internacional privado en materia de conflictos de jurisdicción, y de ley aplicable sobre el asunto. La cooperación jurídica internacional puede ser un camino, en la armonización de las reglas del derecho internacional privado, para la exigencia de responsabilidad civil en el ambiente virtual, tanto por violaciones de terceros como por las empresas gigantes de internet.

En la legislación brasileña, la responsabilidad civil es un mecanismo de carácter general que se destina a responsabilizar a la persona natural o jurídica, que cause daño a otro, y establece la obligación de reparar los perjuicios sufridos, independientemente del origen del daño. Tanto la Ley de Introducción a las Normas de Derecho Brasileño, el Código Civil, el Código de Proceso Civil y la Ley Marco Civil de Internet, coinciden en la exclusividad de la aplicación de las normas brasileñas a las empresas extranjeras en sus actividades latus sensus, determinando como regla de competencia internacional a la jurisdicción brasileña en forma exclusiva, cuando el hecho (daño) haya sido practicado en territorio brasileño y cuando la obligación deba ser cumplida en Brasil. De este modo, la jurisprudencia del Supremo Tribunal Federal y del Tribunal Superior de Justicia alejaron la tesis de incompetencia de jurisdicción, determinando que las empresas gigantes de internet pueden ser juzgadas y condenadas por incumplir con la obligación de no hacer, o sea, de retirar el contenido ofensivo publicado por terceros, que esté bajo su dominio en internet.

La Ley Marco Civil de Internet por su parte, como norma específica vigente para regular cuestiones de internet, protege el derecho a la personalidad y a la protección de datos, y aleja la idea de censura del contenido insertado en internet. Esta norma crea un nuevo tipo de 
responsabilidad civil para las empresas gigantes de internet, no siendo ni objetiva ni subsidiaria, en relación a los daños causados por terceros, esto es, la responsabilidad civil por daños derivados del contenido generado por terceros por incumplimiento de una orden judicial, lo que obliga a retirar el contenido declarado ofensivo.

Las empresas gigantes de internet, en su mayoría, tienen su sede en Estados Unidos y China, por lo que la ausencia de normas de derecho internacional genera conflictos tanto de naturaleza jurídica como política. La falta de cumplimiento de las decisiones judiciales es sustentada sobre el argumento que únicamente se someten a la legislación local-nacional en cuestiones contractuales, ya que la jurisdicción aplicable es la del país donde radica su sede o casa matriz.

La responsabilidad civil transnacional depende de una norma internacional, que sea capaz de armonizar principios ya existentes en varias legislaciones, como la aplicación de la regla del lugar del daño (lex damni) y el principio del foro competente para el daño causado (foro damni). La promoción del respeto a los derechos humanos en el contexto social globalizado implica que el uso de internet necesita un consenso global y requiere de la cooperación jurídica internacional entre los Estados.

La responsabilidad civil enfrenta hoy dos desafíos sin soluciones a corto plazo en el ámbito internacional: el reconocimiento y cumplimiento de las decisiones judiciales que envuelven responsabilidad civil transnacional; y la retirada del contenido que se "viraliza" en internet y que ocasiona daños a terceros. Es una urgencia internacional de los países en el mundo globalizado de hoy resolver estas cuestiones.

\section{BIBLIOGRAFÍA}

Agencia Brasil, "IBGE: celular se consolida como o principal meio de acesso à internet no Brasil", 2016, disponible en línea: http://agenciabrasil.ebc. com.br/geral/noticia/2016-12/ibge-celular-se-consolida-como-o-principal-meiode-acesso-internet-no-brasil, 22 de diciembre de 2018.

Calvo, Alfonso; CARrascosa, Javier, Derecho internacional privado, Comares, Granada, 2014, $15^{\text {a }}$ Edición, p. 677.

Castells, Manuel, Comunicación y Poder, Alianza Editorial S.A., Madrid, 2011, p. 110.

Conjur, "Google deve retirar da internet vídeo de Nissim Ourfali", en línea: http:/www.conjur.com.br/2012-out-27/justica-determina-quegoogle-retire- 
internet-video-nissim-ourfali\#top, 30 de agosto de 2018.

Conjur, "Google é obrigado a excluir todos os vídeos de Nissim Ourfali do YouTube", en línea: httpp://www.conjur.com.br/2016-mar-15/google-obrigadoexcluir-videos-nissim-ourfali-youtube, 20 de febrero de 2018.

DAVENPORT, Thomas, Big data no trabalho: derrubando mitos e descobrindo oportunidades, Elsevier, Rio de Janeiro, 2014.

De Bessa, Paulo, Dano ambiental: uma abordagem conceitual, Lumen Juris, Rio de Janeiro, 2000, p. 118.

De Sousa Gonçalves, Anabela, "The Application of Rome II on the Internet Torts", Masaryk University Journal of Law and Technology, 2014, Vol. 8, №1, p. 39.

GeIsT, Michael, "Is there a there there - toward greater certainty for internet jurisdiction” Berkeley Technology Law Journal, 2001, Vol. 16 n 3, en línea: http:// scholarship.law.berkeley.edu/cgi/viewcontent.cgi?article $=1331 \&$ context $=\mathrm{btlj}, \quad 8$ de diciembre 2018.

Goldschmidt, Werner, Derecho internacional privado - Derecho de la tolerancia, Depalma, Buenos Aires, 1992, $8^{a}$ edición.

GuimarãEs, Thiago, "Responsabilidade civil de provedores de conteúdo da internet”, Revista Brasileira de Direito Civil (Rio de Janeiro), 2015, vol. 4. pp. 98 ss.

HARTLEY, Trevor, "Mandatory rules in international contracts: the common law approach", Business regulation and consumer protection (Londres), 2010, vol. 59, p. 506.

Laudati, Laraine, Summaries of EU Court Decisions Relating to data Protection 2000-2015, OLAF European Anti-Fraud Office, 2016, disponible en línea: https://ec.europa.eu/anti-fraud/sites/antifraud/files/caselaw_2001_2015_ en.pdf, 4 de agosto de 2018.

LÉvy, Pierre, Cibercultura, Editora 34 Ltda., São Paulo, 1999, p. 199.

Lopes Matos, Inez, "A proteção do Consumidor Internacional no Comércio Eletrônico", Tesis de Maestría en Derecho, Universidad de São Paulo, Brasil, no publicada, 2002.

Lotufo, Renan. "Responsabilidade Civil na Internet”, en Greco, M.; Martins, I. (Coord.), Direito e Internet: relações jurídicas na sociedade informatizada, Ed. Revista dos Tribunais, São Paulo, 2001, p. 212.

Lutzi, Tobias, "Internet Cases in EU Private International Law - developing a Coherent Approach", International and Comparative Law Quarterly, 2017, Vol. 66 (3), p. 688.

Mazumder, Anirban, Database Law: Perspectives from India, Springer, Singapore, 2016, p.2.

Meinberg Ceroy, Frederico, "Os conceitos de provedores no Marco Civil da Internet", disponible en línea: http:/www.migalhas.com.br/ dePeso/16,MI211753,51045-Os + conceitos + de + provedores + no + Marco + Civil + da +Internet, 30 de enero de 2019. 
Oster, Jan, "Rethinking Shevill: Conceptualising the EU Private International Law of Internet Torts against Personality Rights", International Review of Law, Computers \& Technology, 2012, Vol. 26, pp. 113-128.

SANOU, Brahima, ICTfacts and figures 2018, International Telecommunication Union, Ginebra, 2018.

Schertel, Laura, Privacidade, proteção de dados e defesa do consumidor: linhas gerais de um novo direito fundamental, Saraiva, São Paulo, 2014, p.181182.

Soler, Israel; Guillermo, William, “Como establecer la jurisdicción y competencia en casos de internet? Tendencias internacionales y nacionales", Diálogos de saberes, 2014, $\mathrm{N}^{\circ}$ 41, p. 15-32.

Sparrow, Andrew, The Law of Virtual Worlds and Internet Social Networks, Gower Publishing Limited, Burlington, 2010, p. 235.

TRIMBLE, Marketa, "The Multiplicity of Copyright Laws on the internet", Fordham Intellectual Property, Media and Entertainment Law Journal (Las Vegas), 2016, Vol. XXV, pp. 339-404.

Ulloa Coelho, Fabio, Direito Civil. Parte Geral, Editora Saraiva, Sao Paulo, 2012, 5a edición, p. 265.

Jurisprudencia citada

Tribunal Superior de Justicia (Brasil), 11 de abril de 2012, Recurso Especial 12.5916 -RJ. (2012/0257814-0).

Tribunal Superior de Justicia (Brasil), 11 de mayo de 2010, Recurso Especial 1.168.547-RJ (2007/0252908-3).

Tribunal Superior de Justicia (Brasil), 13 de diciembre de 2013, Recurso Especial 1328706-MG (2012/0122546-0).

Tribunal Superior de Justicia (Brasil), 17 de abril de 2013, Recurso Especial 784. DF- (2012. 0107506-0).

Tribunal Superior de Justicia (Brasil), 26 de junio de 2012, Recurso Especial 1.316.921 - RJ (2011/0307909-6).

Tribunal Superior de Justicia (Brasil), 29 de agosto 2013, Recurso Especial $N^{\circ} 370.461-$ SP (2013/0206016-2).

Tribunal Superior de Justicia (Brasil), 29 de agosto de 2013, Recurso Especial 370461-SP (2013/0206016-2).

Tribunal Superior de Justicia (Brasil), 30 de junio de 2015, Recurso Especial 690.123-MG (2015/0069500-8).

United States District Court for the Western District of Pennsylvania (EEUU), 16 de enero de 1997, 952 F. Supp. 1119, http://www.internetlibrary.com/ pdf/Zippo-Manufacturing-Zip-Dot-Com-WD-Pa.pdf, 5 de septiembre de 2018. 
Normas citadas

Decreto Legislativo No 129, 5 de octubre de 1995 (Brasil).

Decreto No 2.095, de 17 de diciembre de 1996 (Brasil).

Departamento de Protección y Defensa del Consumidor(Brasil), Despacho $\mathrm{N}^{\circ}$ 137/2014/SENACON/GAB, 22 de julio de 2014, disponible en línea: http:/www. telesintese.com.br/mj-multa-oi-em-r-35-milhoes-por - monitorar-navegacao-declientes-banda-larga, 30 de agosto de 2018.

Directiva $N^{\circ}$ 2000/31/EC, del Parlamento Europeo y del Consejo de la Unión Europea, 2000.

Ley $\mathrm{N}^{\circ}$ 4.657, 1942 (Brasil). Ley de introducción a las normas del derecho brasileiro, Artículo 11, $\S 1^{\circ}$, disponible en línea: http://www.planalto.gov.br/ ccivil_03/decreto-lei/Del4657compilado.htm, 1 de agosto de 2018.

Ley N ${ }^{\circ} 8.078,1990$ (Brasil). Código de Protección y Defensa del Consumidor, http://www.planalto.gov.br, 20 de febrero de 2018.

Ley $\mathrm{N}^{\circ}$ 10.406, 10 de enero de 2002 (Brasil). Código de Derecho Civil Brasileiro, documento disponible en línea: http://www.planalto.gov.br/ccivil_03/ leis/2002/L10406.htm, 1 de septiembre de 2018.

Ley $\mathrm{N}^{\circ} 12.414,2011$ (Brasil).

Ley $\mathrm{N}^{\circ}$ 12.527, 2011 (Brasil).

Ley $\mathrm{N}^{\circ} 12.965$, de 2014 (Brasil). Ley Marco Civil de Internet, disponible en línea: http://www.planalto.gov.br/ccivil_03/_ato2011-2014/2014/lei/112965.htm, 20 de febrero de 2018.

Ley N ${ }^{\circ}$ 13.105, 2015 (Brasil), Código de Proceso Civil, disponible en línea: http://www.planalto.gov.br/ccivil_03/_ato2015-2018/2015/lei/113105.htm, 10 de agosto de 2018.

Ley $\mathrm{N}^{\circ}$ 13.709, 14 de agosto de 2018 (Brasil). Ley de Datos Personales, http://www.planalto.gov.br/ccivil_03/_Ato2015-2018/2018/Lei/L13709.htm, 6 de febrero de 2019.

Reglamento $N^{\circ}$ 1215/2012 del Parlamento Europeo y del Consejo de la Unión Europea, 2012. (Bruselas I bis).

Reglamento N 593/2008 del Parlamento Europeo y del Consejo de la Unión Europea, 2008. (Roma I).

Reglamento N 864/2007 del Parlamento Europeo y del Consejo de la Unión Europea, 2007. (Roma II). 